\title{
Menelusuri Jejak dan Upaya Menghubungkan Sains dan Agama
}

\author{
Paulus Eko Kristianto \\ Mahasiswa Pascasarjana Sekolah Tinggi Filsafat Driyarkara Jakarta \\ paulusekokristianto@gmail.com
}

\begin{abstract}
Looking for a connection between science and religion to be a struggle of its own throughout history. Many thinkers and schools of thought try to formulate them, among them critical realism, anti reductionism, creationism, and intelligent design. The hypothetical alignment connection is expected to provide transcontinental, transcontextual, and global expanse of connections. The stretch here refers to the religion is supposed to illuminate science, and vice versa. Science and religion must be strived to enter in the same best condition because both have sought the truth in various ways. If necessary, the connection is attempted to enter into integration, although occasionally it can enter into conflict methodology.
\end{abstract}

\begin{abstract}
Abstrak
Mencari hubungan antara sains dan agama menjadi pergumulan sendiri sepanjang sejarah. Banyak pemikir dan aliran pemikiran mencoba merumuskannya, di antaranya realisme kritis, anti reduksionisme, kreasionisme, dan intelligent design. Hubungan kesejajaran hipotetis diharapkan tersedianya bangunan hubungan bersifat transkontinental, transkontekstual, dan bentangan-bentangan global. Bentangan di sini merujuk pada agama diharapkan harus menerangi sains, dan sebaliknya. Sains dan agama harus diupayakan masuk dalam kondisi yang sama-sama terbaik karena keduanya telah mencari kebenaran dengan berbagai jalan. Bila perlu, hubungan itu diupayakan masuk pada integrasi, walaupun sesekali bisa masuk ke metodologi konflik.
\end{abstract}

Article History

Submit:

10 September 2018

Revised:

04 October 2018

Accept:

10 October 2018

Keywords:

science; religion; theology; critical realism; antireductionism; creationism; intelligent design

\section{Kata kunci:}

sains; agama; teologi; realisme kritis; anti reduksionisme; kreasionisme; intelligent design,

\section{Pendahuluan}

Sebagaimana kita ketahui pada zaman Pra-Pencerahan, teologi (agama) sempat terkesan berkuasa di atas ilmu sebagai Regina Scientiarum, "the Queen of Sciences", "Ratunya ilmu-ilmu". Lalu, ilmu-ilmu lainnya telah merujuk pada ajaran gereja (agama). Sebagai contoh dalam kurun waktu yang lama, orang menerima pandangan Ptolomaeus 
mengenai bumi sebagai pusat pusat alam semesta (biasa disebut geosentris). Hal tersebut terjadi karena pandangan ini berpadanan dengan keterangan dalam Kitab Suci yang menerangkan dunia ini sebagai alam ciptaan. Oleh karena itu, gagasan lawannya yang menerangkan matahari sebagai pusat alam semesta (biasa disebut heliosentris) akan dianggap sebagai ajaran sesat. Sebagai catatan pada konteks tersebut, setiap ajaran yang dicap sebagai sesat akan berdampak pada hukuman mati. Oleh karenanya semasa hidupnya, Kopernikus tidak berani mengenalkan pandangannya. Kemudian, pandangannya barulah muncul setelah beliau meninggal.

Berbeda dengan zaman Pra-Pencerahan, era Pasca-Pencerahan menunjukkan kalau ilmu pasti dan alam telah merebut posisi yang ditempati teologi (agama) sehingga ilmu-ilmu tersebut menjadi ratu ilmu hingga sekarang. ${ }^{1}$ Hal ini semakin nyata ketika majalah Time mendeskripsikan Albert Einstein dianggap sebagai "Person of the Century". Ilmu pasti dan alam dinyatakan sebagai rujukan dalam membangun gambaran dunia masa kini. ${ }^{2}$ Akhirnya, teologi (agama) telah kehilangan sifat akademik dan dijadikan wawasan secara spiritual yang perlu diketahui dalam rangka persiapan seseorang menjadi pelayan jemaat (contohnya pendeta). Kondisi demikian membawa konsekuensi logis bahwa pandangan kedudukan bumi yang tadinya sebagai pusat menjadi terguncang, dan akhirnya terpaksa digantikan matahari sebagai pusat.

Kita melihat penerimaan terhadap pemahaman Newton mengenai determinisme menyebabkan orang melihat Yang Ilahi sebagai perancang atau bahkan penentu jalan orang. Jalan Tuhan adalah pasti. Akan tetapi, munculnya teori kuantum dari Bohr dan teori ketidakpastian dari Heisenberg pada tahun 1940-an menyebabkan banyak orang membangun teologi (agama) baru. Teologi baru tersebut menunjukkan Yang Ilahi sebagai Dia yang membebaskan daripada menentukan. Lalu, Iman bukan kepastian tetapi justru kegamangan, seperti Abraham yang berani meninggalkan negeri nenek moyangnya meskipun belum jelas ke mana ia akan pergi.

Perdebatan hubungan sains dan agama makin meruncing dengan adanya literatur di kalangan Kristiani yang menyinggung hubungan iman (agama) dengan teori evolusi. ${ }^{3}$ Kalangan Katolik banyak diperkenalkan dengan pemikiran Teilhard de Chardin. De Chardin

\footnotetext{
${ }^{1}$ Robert John Russell. Theological Influences in Scientific Research Programs: Natural Theology "in Reverse". Theology and Science Journal, Volume 15, 2017, Issue 4, 380. https://doi.org/10.1080/14746700.2017.1369751

${ }^{2}$ Ibid.

${ }^{3}$ Ted Peters. Science and Religion: Ten Models of War, Truce, and Partnership. Theology and Science Journal, Volume 16, 2018, Issue 1, 12. https://doi.org/10.1080/14746700.2017.1402163
} 
berusaha mencapai sintesis antara tradisi Katolik dan teori evolusi. ${ }^{4}$ Sedangkan, dari kalangan Protestan muncul buku-buku yang cukup seimbang dengan menjelaskan kaitan iman, ilmu, dan Kitab Suci, seperti karangan Petrie dan Mulder. ${ }^{5}$ Buku-buku tersebut mengkaji adanya masalah ketegangan yang muncul dari dalam diri orang Kristen. Ketegangan ini menunjukkan keberadaan manusia yang sebagian besar unsur kimianya adalah air, tetapi di pihak lain Kitab Kejadian menunjukkan manusia berasal dari tanah.

Penjelasan manusia berasal dari tanah bermaksud menyampaikan bahwa manusia merupakan mahkluk fana dapat mati, dan akan kembali ke tanah apabila ia mati. Penjelasan ini sedikit melegakan. Tetapi, penjelasan demikian bisa sedikit tergoyahkan ketika berhadapan dengan berbagai persoalan lainnya. Mungkin, kita bisa mengatakan gambaran dunia sains dan agama masing-masing memiliki hak untuk diapresiasi. Namun, apresiasi ini tidak menuntut salah satunya dieliminasi. Masalahnya, apakah semudah itu? Bagaimana model metodologi yang tepat guna menggambarkan hubungan keduanya? Serta, bagaimana implementasinya dalam perkembangan sains dan agama?

Cara yang ditempuh untuk membangun hubungan antara sains dan agama menunjukkan sebagian besar ditentukan oleh bagaimana orang menjawab pertanyaan “mengapa hubungan harus dibangun?" Setidaknya dalam membangun hubungan, kita harus mengetahui adanya kesejajaran hipotetis. Ted Peters mengatakan kesejajaran hipotetis berangkat dari adanya asumsi bahwa sains dan agama berupaya menemukan arti realitas tunggal walaupun hal ini terasa sulit dan banyak seginya. ${ }^{6}$ Dalam mengikatkan diri dengan kesejajaran hipotetis, sains dan agama dapat dimungkinkan telah mengambil risiko. Risiko tersebut berkenaan dengan agama menyetujui perkiraan-perkiraannya diteliti secara ilmiah serta berasumsi bahwa deskripsi ilmiah atas dunia alam mungkin berguna bagi wawasan keagamaan. Sedangkan, sains menyetujui perkiraan-perkiraannya yang diteliti secara keagamaan tentang hakikat realitas secara ilmiah. Melalui risiko demikian, asumsi-asumsi dalam lingkup kesejajaran hipotetis dapat masuk pada program penelitian bersama dan terkukuhkan dengan mengkukuhkan serta menolak klaim bersama.

Hubungan kesejajaran hipotetis diharapkan tersedianya bangunan hubungan bersifat transkontinental, transkontekstual, dan bentangan-bentangan global. Bentangan di sini

\footnotetext{
${ }^{4}$ Ilia Delio OSF. Is Natural Law “Unnatural?” Exploring God and Nature Through Teilhard's Organic Theology. Theology and Science Journal, Volume 15, 2017, Issue 3, 276-288. https://doi.org/10.1080/14746700.2017.1335063

${ }^{5}$ Christian Early. Theology After the Scientific Revolution: The Significance of Nancey Murphy's Contribution to Philosophy of Religion. Theology and Science Journal, Volume 15, 2017, Issue 4, 440. https://doi.org/10.1080/14746700.2017.1369756

${ }^{6}$ Gaymon Bennett, "Pendahuluan" dalam Ted Peters dan Gaymon Bennet (Peny.), Menjembatani Sains dan Agama terj. Jessica Christiana Pattinasarany (Jakarta: BPK Gunung Mulia/ CTNS, 2006), 17.
} 
merujuk pada agama diharapkan harus menerangi sains, dan sebaliknya. Dalam membangun hubungan tersebut, kita harus memiliki persamaan pemahaman yakni teologi merupakan refleksi intelektual atas tradisi agama. Dengan kata lain, ketika kita berbicara teologi, maka tidak bisa dilepaskan dari agama. ${ }^{7}$ Sedangkan, sains cenderung mengacu pada ilmu alam, di antaranya fisika, kosmologi, biologi (biologi evolusioner dan genetika), dan ilmu syaraf. Namun, sains tidak menutup kemungkinan pada adanya ilmu sosial.

\section{Metodologi}

Bentuk nyata hubungan kesejajaran hipotetis dapat terlihat pada kehadiran berbagai tipe metodologi. Dalam penyajiannya, penulis menggunakan bingkai metodologi menghubungkan sains dan agama menurut Ian Barbour. Ian Barbour memetakan hubungan sains dan agama setidaknya berupa konflik, kemandirian, dialog, dan integrasi. ${ }^{8}$ Metodologi konflik menyajikan pernyataan bahwa materialis ilmiah mengklaim dunia hanya terdiri dari materi semata, dan tidak ada ruang bagi jiwa, roh, atau Allah. Bahkan, sains dipandang sebagai satu-satunya jalan untuk memperoleh pengetahuan. Sedangkan, agama tidak dilihat berharga dalam kehidupan. Di sisi lain, penganut literalis Alkitabiah percaya bahwa Alkitab harus dibaca secara harafiah dan tanpa adanya penafsiran. Melalui pola demikian, mereka meyakini Alkitab dapat memberikan pengetahuan yang benar tentang dunia, kemanusiaan, dan Allah. Maka, sains kerap dipandang negatif oleh penganut literalis Alkitab karena dianggap sebagai tantangan Alkitabiah.

Berikutnya adalah metodologi kemandirian; di mana sains dan agama tetap tinggal terpisah satu sama lain. Dalam hal ini, sains dan agama tidak sedang mengalami konflik serta tidak berinteraksi dan dialog. Posisi ini terjadi karena sains dan agama telah menggunakan metode penelitian yang berbeda. Sebagai contoh, Peters menerangkan akal berlawanan dengan iman karena sains berdasarkan fakta sementara agama berpijak pada nilai religius. Selain itu, sains yang menggunakan bahasa ilmiah cenderung mengacu melihat gambaran dunia, sedangkan agama memakai bahasa guna melukiskan emosi, harapan, dan kepercayaan.

Dialog dipahami sebagai model yang menghubungkan sains dan agama dengan mencakup mencari jawaban atas pertanyaan-pertanyaan seputar batas dan kesejajaran metodologi. Pertanyaan tersebut biasanya diungkapkan berupa "Apabila alam semesta

\footnotetext{
${ }^{7}$ Kevin Tonny Rey, “Konstruksi Teologi Dalam Konteks Reposisi Pemikiran Warga Gereja," EPIGRAPHE: Jurnal Teologi dan Pelayanan Kristiani 2, no. 1 (2018): 1-13, www.stttorsina.ac.id/jurnal/index.php/epigraphe.

${ }^{8}$ Robert John Russell dan Kirk Wegter-Monelly, "Sains dan Teologi: Interaksi Timbal-Balik" dalam Ted Peters dan Gaymon Bennet (Peny.), Menjembatani Sains dan Agama, 24-26.
} 
memiliki awal, apakah yang terjadi setelah itu?", "Mengapa kita merasakan belas kasihan atau altruisme?", "Mengapa alam semesta itu ada?". Semua pertanyaan tersebut dicoba mencari jawaban dengan cara sains dan agama sama-sama berdialog dengan menggunakan data empiris untuk sains, kemudian Kitab Suci, pengalaman religius, dan liturgi untuk agama. Dengan demikian, proses tersebut telah menggunakan akal dan nilai-nilai untuk memilih dan menentukan teori tertentu guna menjawab pertanyaan yang ada.

Metodologi integrasi menunjukkan adanya pertemuan antara sains dan agama secara sintesis sehingga menghasilkan kajian baru. Tujuan sintesis di sini berupaya menggabungkan keduanya dalam suatu kerangka tunggal. Melalui cara demikian, konsep ruang, waktu, materi, kausalitas, pikiran, roh, dan Allah telah digunakan secara sintesis dalam teori dan penelitian teologis maupun ilmiah. Contoh model ini yakni lahirnya teologi natural. Teologi natural memulai kerangka kerjanya dari teologi dan kemudian berupaya menggabungkan pada penemuan sains. ${ }^{9}$

Dalam perjalanan waktu, hubungan sains dan agama telah mengalami perkembangan. Sepanjang tahun 1980 dan 1990-an, berbagai tipe menghubungkannya mulai bermunculan. ${ }^{10}$ Arthur Peacocke menampilkan perbedaan dan persamaan yang ada dalam bidang, pendekatan, bahasa, serta sikap teologi dan agama. Di sisi lain, John Haught menawarkan model konflik, kontras, kontak, dan konfirmasi. Peters melihat tiga model pertama menurut Haught sama halnya dengan Barbour, sedangkan model konfirmasi sedikit berbeda. Bagi Haught, model konfirmasi merupakan bentuk asumsi filosofis yang mendasari sains dengan berakar dalam teologi. Contoh pernyataannya yaitu Allah menciptakan alam semesta sebagai suatu tindakan bebas, kemudian Allah dipandang sebagai suatu kemungkinan yang dapat saja menciptakan alam dengan sangat berbeda dari sekarang. ${ }^{11}$

\section{Pembahasan}

\section{Realisme Kritis}

Dalam konteks menghubungkan sains dan agama, realisme kritis merupakan sebuah alternatif terhadap tiga pandangan filsafat mengenai sains. Menurut Barbour, tiga pandangan tersebut merujuk pada ${ }^{12}$; (1) Menurut realisme klasik, teori ilmiah telah memberikan gambaran "fotografis" tentang dunia. (2) Menurut kaum instrumentalis, teori ilmiah hanyalah

\footnotetext{
${ }^{9}$ Michael J. Dodds OP. Thomas Aquinas vis-à-vis Natural Theology, Theology of Nature, and Religious Naturalism. Theology and Science Journal, Volume 15, 2017, Issue 3, 270. https://doi.org/10.1080/14746700.2017.1335062

${ }^{10}$ Peters. Naturalisms: Scientific? Religious? Theological? Theology and Science Journal, Volume 15, 2017, Issue 3, 315. https://doi.org/10.1080/14746700.2017.1335059

${ }^{11}$ Russell dan Monelly, "Sains dan Teologi: Interaksi Timbal-Balik", 26.

${ }^{12}$ Russell dan Monelly, "Sains dan Teologi: Interaksi Timbal-Balik", 27-28.
} 
merupakan alat kalkulatif semata. (3) Kaum idealis melihat teori ilmiah telah menggambarkan realitas bersifat mental atau ideasional. Dengan demikian, realisme kritis mencoba menawarkan teori ilmiah dilihat melalui metafora. Metafora dapat dikatakan sebagai analogi terbuka di mana maknanya tidak dapat diungkapkan melalui harafiah saja, melainkan dikembangkan dalam berbagai model sains.

Berpijak pada metafora tersebut, Barbour telah berpaling pada filsuf sains kontemporer, di antaranya Carl Gustav Hempel. Hempel menerangkan setiap penjelasan sebenarnya merupakan jawaban atas pertanyaan mengapa. Penjelasan tidak melulu menampilkan alasan ideal, melainkan berkenaan dengan sebab akibat yang memiliki struktur logis tertentu. ${ }^{13}$ Barbour melihat poin penting dari pemikiran Hempel harus diperhatikan pada adanya teori dan data yang telah membentuk suatu simpul hipotesis-deduktif. Simpul tersebut menyajikan analogi dan model imajinatif dengan berpijak pada data, dan sementara teori telah membawa ranah prediksi yang meluas. Walau demikian, Barbour tetap mengingatkan bahwa hubungan sains dan agama sebenarnya hanyalah upaya membangun argumentasi filsafat sains yang sejajar dengan agama. Dengan kata lain, sains dan agama sama-sama telah membuat klaim kognitif tentang dunia melalui metode hipotesis-deduktifnya. Integrasi sains dan agama diharapkan melahirkan proses pengamatan dan pengalaman melalui berbagai model yang bersifat analogis, diperluas, koheren, simbolis, dan dapat dinyatakan melalui metafora. Integrasi sains dan agama yang dinyatakan melalui metafora biasa ditemukan dalam karya Sallie McFague dan Janet Soskice. McFague menggambarkan teologi (agama) model telah menyediakan tatanan, sementara sains menawarkan penemuan baru. Sedangkan, Soskice menekankan adanya perbedaan antara metafora dan model. Soskice secara gigih membela realism teologis sambil menekankan sifat sosial dan kontekstual dari realisme ilmiah.

\section{Anti-Reduksionisme}

Sebagian besar pakar sains dan teologi (agama) telah menerima adanya reduksionisme metodologis. Walau demikian, mereka melihat bentuk reduksionisme yang lain telah menurunkan kredibilitas disiplin pada aras yang lebih tinggi. Arthur Peacocke mengembangkan tataran ini dalam dua dimensi yakni vertikal dan horisontal. Secara vertikal, dimensi ini terdiri dari aras-aras yang makin tinggi makin kompleks, contohnya dunia fisik, organisme yang hidup, perilaku mereka, serta kebudayaan manusia. Sedangkan secara horizontal, dimensi ini mengatur sistem dalam hierarki bagian keseluruhan, contohnya beberapa kajian dalam biologi, yaitu makromolekul, sel, organ, organisme individual,

\footnotetext{
${ }^{13}$ Mikhael Dua. Filsafat Ilmu Pengetahuan (Maumere: Ledalero, 2009), 88.
} 
populasi, dan ekosistem. Bila dilihat lebih jauh, pemikiran Peacocke menunjukkan adanya kesepakatan yang luas dari komunitas ilmiah tentang cara bagaimana berbagai disiplin ilmiah saling berkaitan dan bergantung satu sama lainnya.

Interaksi konstruktif antara sains dan teologi (agama) telah mempermudah para kritikus asumsi reduksionistis bekerja di bidang materialisme ilmiah. Dalam hal ini, Fransisco Ayala memetakannya dalam tiga hal berikut ${ }^{14}$; [1] Reduksionisme metodologis merupakan strategi penelitian guna mempelajari keseluruhan dari berbagai segi bagian-bagiannya dan proses untuk menerapkan teori yang berhasil di satu bidang ke bidang yang lain. [2] Reduksionisme epistemologis merupakan klaim bahwa proses, sifat, hukum, atau teori pada tingkat kompleksitas yang lebih tinggi seluruhnya dapat diturunkan dari tingkat yang lebih rendah. [3] Reduksionisme ontologis merupakan pandangan bahwa entitas pada aras yang lebih tinggi semata-mata ialah organisasi yang kompleks dari entitas yang lebih sederhana. Dalam perjalanannya, Nancey Murphy menambahkan pemetaan Ayala menjadi dua lagi yakni; [4] Reduksionisme klausal merupakan penegasan bahwa semua sebab berasal dari bawah ke atas. Hal ini berarti ciri-ciri dan proses dari bagian-bagian sepenuhnya menentukan ciri-ciri dan proses dari keseluruhan. [5] Materialisme reduktif menjelaskan hanya entitas pada aras terendahlah yang benar-benar nyata. Namun, Murphy telah menolak mateialisme reduktif dengan pertimbangan bahwa entitas yang lebih tinggi pun tetap bersifat nyata dan tidak hanya terbatas pada aras terendah.

\section{Penciptaan dan Kosmologi}

Proses terbentuknya bumi dan alam semesta biasa diuraikan dalam dua paparan, yaitu sains dan teologi (agama). ${ }^{15}$ Sains diawali melalui penjelasan mengenai ledakan besar (The Big Bang). Secara kronologi tahun, Louis Leahy menjelaskannya dalam tahun 1917-1983. ${ }^{16}$

\begin{tabular}{|c|l|}
\hline Tahun & \multicolumn{1}{|c|}{ Uraian Penjelasan Peristiwa Penting } \\
\hline 1917 & $\begin{array}{l}\text { Wiliem de Sitter mempelajari persamaan relativitas umum Einstein. } \\
\text { Proses pelajaran ini menemukan suatu jawaban yang meramalkan adanya } \\
\text { suatu alam semesta yang semakin meluas. }\end{array}$ \\
\hline 1929 & $\begin{array}{l}\text { Edwin Hubble melakukan pengujian "pergeseran merah" cahaya dari } \\
\text { nebula jauh, merumuskan hukum Nebula. Hukum tersebut mengulas } \\
\text { kecepatan resesi sebuah nebula yang bersifat proporsional terhadap } \\
\text { jaraknya dari kita. Jika diekstrapolasi ke arah waktu lampau, alam semesta } \\
\text { tampaknya meluas dari suatu permulaan yang umum sekitar 15 milyar } \\
\text { tahun yang lalu. }\end{array}$ \\
\hline
\end{tabular}

\footnotetext{
${ }^{14}$ Russell dan Monelly, "Sains dan Teologi: Interaksi Timbal-Balik”, 33.

${ }^{15}$ Marojahan Saragi, “Ancaman Evolusionisme Terhadap Pendidikan Kristen," KURIOS (Jurnal Teologi dan Pendidikan Agama Kristen) 3, no. 1 (2015): 40-47, www.sttpb.ac.id/e-journal/index.php/kurios.

${ }^{16}$ Louis Leahy. Sains dan Agama dalam Konteks Zaman Ini (Yogyakarta: Kanisius, 1997), 51-52.
} 


\begin{tabular}{|l|l|}
\hline \multirow{3}{*}{1965} & $\begin{array}{l}\text { Arno Penzias dan Robert Wilson mulai menemukan latar belakang yang } \\
\text { samar mengenai gelombang mikro yang muncul dari segala arah dalam } \\
\text { ruang angkasa. Spektrum gelombang ini sangat sesuai dengan radiasi } \\
\text { residu 3 K yang telah diramalkan dalam teori relativitas. Radiasi di sini } \\
\text { merupakan pancaran akhir dari bola api kosmis yang didinginkan melalui } \\
\text { perluasannya lebih lanjut. }\end{array}$ \\
\hline 1967 & $\begin{array}{l}\text { Stephen Weinberg dan Abdus Salam memperlihatkan bahwa daya } \\
\text { elektromagnetik dan daya lemah dapat disatukan dalam suatu Teori } \\
\text { Elektro-Lemah. Teori ini meramalkan eksistensi dua partikel besar, boson } \\
\text { W dan Z. }\end{array}$ \\
\hline 1983 & $\begin{array}{l}\text { Carlo Rubbia dan rekan-rekannya menemukan partikel-partikel dengan } \\
\text { kandungan seperti diramalkan dalam boson W di antara hasil-hasil } \\
\text { tabrakan energi-tinggi dalam akselerator CERN di Genewa. }\end{array}$ \\
\hline
\end{tabular}

Berdasarkan informasi di atas, kita bisa mengetahui bahwa fakta-fakta astronomi dan Fisika energi-tinggi dengan adanya sebuah rekonstruksi yang masuk akal melalui sejarah kosmis. Dua belas milyar tahun sesudah ledakan besar, bentuk-bentuk kehidupan mikroskopis telah mulai muncul di planet kita. Satu milyar dari permulaan tersebut, galaksi dan bintangbintang mulai bermunculan. Hal ini disebabkan oleh saat $\mathrm{t}=5.000 .000$ tahun, atom-atom pembentuk mulai muncul. Peristiwa tersebut terjadi hanya tiga menit dari permulaan itu di mana bagian inti (nukleus) mulai terbentuk dari proton dan neutron. Dengan demikian, teori yang masuk akal mulai berkaitan dengan berbagai peristiwa penting pembentuk bumi dan alam semesta lainnya.

Walaupun sains mencoba menjelaskan berbagai cara, para ahli sains tetap menyatakan bahwa $\mathrm{t}=0$ tidak dapat dijangkau. Hal tersebut dikarenakan sesuatu yang tampak hanyalah berupa singularitas yang padanya hukum Fisika tidak berlaku. Dengan demikian, hal ini merupakan semacam batas terakhir bagi penyelidikan ilmiah. Sebab, sesuatu yang hanya dapat diperlakukan sebagai sebuah pemberian, meskipun orang dapat berspekulasi mengenainya. Berpijak pada situasi demikian, bagaimana tanggapan hubungan sains dan agama dalam melihatnya? Robert Jastrow (ahli astronomi) mengatakan bukti astronomi membawa pada pandangan Kitab Suci mengenai asal mula dunia. Dalam uraiannya, ia mengakhirinya demikian;

Pada saat ini, sains tampak seolah-olah tidak pernah akan dapat menyibakkan tirai misteri penciptaan. Bagi ilmuwan yang telah menghayati imannya dalam kekuatan akal budi, kisah tersebut berakhir seperti sebuah mimpi buruk. Ia telah mendaki gunung-gunung ketidaktahuan; ia baru saja akan menaklukkan puncaknya yang tertinggi; ketika ia akhirnya berhasil mencapai batu karang terakhir, ia disambut oleh sekelompok para teolog yang telah duduk di sana selama berabad-abad. ${ }^{17}$

\footnotetext{
${ }^{17}$ Robert Jastrow. God and the Astronomers (New York: W. W. Norton, 1978), h. 116 dikutip Louis Leahy. Sains dan Agama dalam Konteks Zaman Ini, 56.
} 
Melihat gagasan tersebut, Leahy menunjukkan kosmologi kontemporer bisa relevan dengan kajian teologi (agama). Contohnya pada masa lalu, orang sering dipanggil untuk menjelaskan jurang-jurang dalam berbagai kisah ilmiah yang ada. Namun, jurang tersebut perlahan telah tertutup karena sains telah menemukan jawabannya sendiri melalui kemajuan teknologi. Walau demikian, Leahy tetap optimis bahwa sains sampai sekarang belum bisa menjawab persoalan peristiwa sebelum $\mathrm{t}=0$ yang tampaknya secara prinsip tidak dapat dimasukkan dan dijawab dalam sains.

Bagaimana bila ledakan besar yang tunggal dan unik semakin tampak sebagai teori ilmiah yang paling meyakinkan? Agama mencoba menjawabnya melalui penjelasan "Ketika Allah mulai menciptakan langit dan bumi, bumi belum berbentuk dan kosong.” Dalam hal tersebut, Allah digambarkan sebagai yang merencanakan dan berkuasa, menciptakan hanya dengan Sabda. Penjelasan kisah penciptaan dalam Alkitab tidak dimaksudkan untuk menyingkirkan berbagai hasil penemuan dari sains, melainkan menjelaskan adanya tatanan yang tercipta itu baik, suatu keseluruhan yang interdependen, sebuah komunitas pengada, dan bukan obyek sembahan kita. ${ }^{18}$

\section{Darwinisme, Kreasionisme, dan Intelligent Design}

Salah satu wujud nyata perdebatan menghubungkan sains dan agama yaitu diskusi antara Darwinisme, Kreasionisme, dan Intelligent Design. Dalam penguraiannya, penulis menggunakan dan mengadaptasi tulisan Franz Magnis-Suseno. Magnis-Suseno menunjukkan perdebatan Darwinisme, Kreasionisme, dan Intelligent Design berangkat dari gerakan modernitas yang menggoncang keyakinan bahwa alam diciptakan oleh Allah (Roma 1: 19, 20; Kis. 17: 27, 28). ${ }^{19}$ Goncangan modernitas tersebut ditandai terbitnya buku "The Origin of Species by Means of Natural Selection or The Preservation of Favoured Races in the Struggle for Life". Dalam buku tersebut, Darwin menunjukkan semua organisme yang kita jumpai sekarang merupakan keturunan dari beberapa organisme amat sederhana dalam sebuah proses perkembangan yang barangkali membutuhkan ratusan juta tahun. Selain itu, Darwin turut menguraikan bahwa manusia merupakan produk dari proses evolusi.

Francisco J. Ayala menunjukkan Darwin telah menerima pemahaman bahwa semua organisme telah dirancang dengan berbagai cara tertentu untuk hidup melalui organ-organ

\footnotetext{
${ }^{18}$ Louis Leahy. Sains dan Agama dalam Konteks Zaman Ini, 64.

${ }^{19}$ Franz Magnis-Suseno, “Allah dan Alam: Darwinisme, Creationism, dan Intelligent Design” dalam Jurnal Diskursus Vol. 8, No. 1, April 2009, 1.
} 
yang sudah disesuaikan guna menjalankan fungsinya. ${ }^{20}$ Oleh karenanya, Ayala memberi contoh ikan diadaptasi hidup di air, dan ginjal dirancang untuk mengatur komposisi darah. Perancangan semua organ tersebut turut memungkinkan organisme mampu bertahan dalam proses seleksi alam. Seleksi alam melebihi proses pemurnian. Seleksi alam mampu menghasilkan hal baru atas berbagai kombinasi generik tubuh organisme. Seleksi alam turut berintegrasi dengan proses mutasi secara kreatif. Dalam hal ini, keduanya dilakukan guna menghadapi keberagaman kehidupan dunia dengan berbagai proses adaptasi yang dilakukan organisme. Guna melewati proses demikian, organisme dimungkinkan sudah dirancang oleh perancang cerdas (intelligent designer). Namun, Ayala menjelaskan dalam proses evolusi, tidak ada entitas atau orang yang mengadaptasi semua kombinasinya secara selektif. Sebab, kombinasi evolusi tersebut sudah dilakukan dan diseleksi langsung oleh organisme itu sendiri. Gagasan tersebut kemudian biasa disebut rancangan tanpa perancang (design without designer).

Proses evolusi menurut Darwin ternyata tidak langsung diterima saja. Hal tersebut terjadi karena adanya pro dan kontra dalam melihatnya. Contohnya di kalangan Katolik, Teolog Teilhard de Chardin mengatakan bahwa evolusi organisme tidak bertentangan dengan keyakinan bahwa Allah menciptakan alam raya, melainkan memperlihatkan keindahannya. ${ }^{21}$ Namun, Francisco J. Ayala mengingatkan gagasan de Chardin terkait sejarah penciptaan (evolusi) bumi berkenaan dengan kompleksitas kesadaran (complexity-consciousness). ${ }^{22}$ Dalam hal ini, de Chardin menyebutnya sebagai "Point Omega" yang turut menunjukkan simbol Allah (symbol for God). De Chardin menjelaskan Omega merupakan sebuah kolektivitas harmonis kesadaran yang setara dengan kesadaran superior (superconsciousness). Gagasan tersebut menunjukkan bahwa bumi tidak hanya sedang dibahas oleh berjuta butir pemikiran tetapi menjadi tertutup amplop pemikiran tunggal sehingga membentuk fungsional dan tidak lebih dari sebutir besar tunggal pemikiran pada skala sidereal ${ }^{23}$, pluralitas refleksi individu pengelompokkan diri bersama-sama dan memperkuat satu sama lain dalam tindakan

\footnotetext{
${ }^{20}$ Francisco J. Ayala, “Darwin's Greatest Discovery: Design without Designer” dalam PNAS, 15 Mei 2007, Vol. 104, Sup. 1, 8567. Lihat Francisco J. Ayala. Darwins's Gift to Science and Religion (Washington DC: Joseph Henry Press, 2007), 42.

${ }^{21}$ Franz Magnis-Suseno, “Allah dan Alam: Darwinisme, Creationism, dan Intelligent Design”, 2.

${ }^{22}$ Kompleksitas kesadaran (complexity-consciousness) mulai dibahas melalui pluralitas dan meningkat menuju kesatuan. Dalam hal ini, kesatuan bukan berupa fusi, melainkan diferensiasi yang bukan saja mempertahankan keaslian bagian-bagian yang membentuk sisntesa tersebu, tetapi juga memperkayanya. Pada tingkat tertentu berkenaan dengan kompleksifikasi materi, beberapa ambang telah dilangkahi dan kualitaskualitas baru mulai timbul; pertama-tama kehidupan, dan kemudian berkembang pada kesadaran manusia. Louis Leahy. Manusia di Hadapan Allah 1: Masalah Ketuhanan Dewasa Ini (Yogyakarta/ Jakarta: Kanisius/ BPK Gunung Mulia, 1982), 128.

${ }^{23}$ Sidereal merupakan skala yang berkenaan dengan bintang.
} 
refleksi bulat tunggal. ${ }^{24}$ Bila diteliti lebih lanjut, de Chardin sebenarnya mengungkapkan visi Omega bertepatan dengan ungkapan Paulus dalam Perjanjian Baru. Paulus sering mengingatkan bahwa ketika semua manusia bersatu dengan Kristus dalam Tubuh Mistik tunggal, maka semuanya akan mencapai kesempurnaan Allah.

Dalam perjalanannya, gagasan Darwinisme tentang evolusi telah ditanggapi secara kritis melalui dua teori, yaitu Kreasionisme dan Intelligent Design.

\section{Kreasionisme}

Ensiklopedia Katolik (The Catholic Encyclopedia) menjelaskan kreasionisme merupakan pengajaran segala macam jenis makhluk hidup yang diciptakan atau diproduksikan pada saat yang sama dan langsung oleh Allah, dan karena itu tidak merupakan produk sebuah proses perkembangan. Magnis-Suseno menunjukkan para penganut kreasionisme meyakini semua jenis organisme telah diciptakan langsung oleh Allah beberapa ribu tahun lalu. Keyakinan mereka setidaknya diyakini berdasarkan dari penjelasan proses penciptaan menurut Kitab Kejadian karena merupakan wujud nyata dari wahyu Allah yang tidak pernah keliru.

Dalam perjalanannya, gagasan Kreasionisme telah mengalami pengujian ketika berhadapan dengan petunjuk yang mendasari teori evolusi, contohnya penemuan berbagai fosil dan pola penyebaran geografisnya bila ditempatkan dalam matriks waktu, pengamatan penyesuaian, dan perbedaan organisme dalam lingkungan terbatas. ${ }^{25}$ Oleh karenanya, pandangan Kreasionisme banyak disanggah dengan ajakan untuk membaca dan menafsirkan kisah Penciptaan dalam kitab Kejadian dengan perspektif terbuka bukan harafiah.

\section{Intelligent Design}

Teori Intelligent Design berbeda dengan Kreasionisme. Kelompok penganut Intelligent Design tidak bersitegang pada pengertian harafiah kitab Kejadian, tetapi sekaligus tanpa menolak anggapan Darwinisme mengenai evolusi sebagai proses kebetulan ilmiah. Magnis-Suseno menegaskan walau Intelligent Design menjelaskan demikian, tetapi kelompok ini tetap memiliki kelemahan sama dengan Kreasionisme. Kelemahan tersebut merujuk pada proses memasukkan Allah ke dalam sebuah teori ilmu Alam. ${ }^{26}$ Oleh karena itu, kritik atas

\footnotetext{
${ }^{24}$ Pierre Teilhard de Chardin. The Phenomenon of Man (New York and Evanston: Harper Torchbook Edition, 1961), 251-252 dikutip Francisco J. Ayala, "The Evolutionary Thought of Teilhard de Chardin" dalam Allen D. Breck dan Wolfgang Yourgrau (eds.) Biology, History, and Natural Philosophy (New York: Plenum Publishing Corporation, 1974), 214.

${ }^{25}$ Bernike Sihombing, "Studi Penciptaan Menurut Kitab Kejadian 1 : 1-31," KURIOS (Jurnal Teologi dan Pendidikan Agama Kristen) 1, no. 1 (2013): 1-31.

${ }^{26}$ Franz Magnis-Suseno, “Allah dan Alam: Darwinisme, Creationism, dan Intelligent Design”, 5.
} 
kelompok ini bernada bahwa Allah bukan bagian dari alam dan justru Dialah yang menciptakan alam ini. Penjelasan tersebut biasa dinyatakan dalam dua kata yakni "transenden" dan "imanen". Transenden berarti Allah mengatasi segala realitas duniawi, sedangkan Imanen berarti sebagai pencipta, Ia mendukung segenap proses yang berlangsung di dunia, sehingga Ia bisa berada di manapun.

Magnis-Suseno menegaskan bahwa teologi kontemporer (mulai dari Karl Rahner) juga menolak argumen dari "irreducible complexity". Argumentasi tersebut berarti ada perkembangan kompleksitas yang tidak dapat dijelaskan melalui berbagai perubahan kecil kebetulan maka perlu adanya intelligent designer. ${ }^{27}$ Bahkan, tidak ada "lobang-lobang" dalam penjelasan ilmiah yang perlu diisi dengan Tuhan, melainkan Darwinisme (termasuk Dawkins) belum dapat menjelaskan sedikitpun mengapa evolusi berkembang dengan sedemikian tidak probabel. Bagi orang percaya, teka-teki evolusi itu menjadi hilang apabila ada Allah yang dalam penciptaannya sudah mengarahkan alam raya pada terjadinya bumi dan perkembangan organisme sampai manusia. Maka, sebagai serangan seorang ilmuwan alam (Dawkins) terhadap kepercayaan pada Allah jelas gagal. Walau demikian, Magnis-Suseno menegaskan Darwinisme (termasuk Dawkins) memiliki jasa yakni ia mengangkat implikasi buruk kepercayaan Kristiani fundamentalis dan tradisionalis, agar menyadari betapa mengerikannya beberapa ajaran dan sikap yang dianggap biasa (lumrah).

\section{Genetika menuju Tantangan Sekarang hingga Masa Depan}

Genetika merupakan bidang penelitian ilmiah yang mempelajari aktivitas gen pada tumbuh-tumbuhan, binatang, dan manusia. Dalam penelitian ini, gen ialah segmen Deoxyribonucleic Acid (DNA) yang terdapat dalam setiap sel. Serabut DNA terdiri dari empat unsur kimia dasar, yaitu adenine $(\mathrm{A})$, guanine $(\mathrm{G})$, cytosine $(\mathrm{C})$, dan thymine $(\mathrm{T})$. Genetika modern berawal pada abad ke-19 melalui penelitian seorang biarawan Austria yakni Gregor Mendel yang menemukan pola-pola warisan dalam tanaman kacang polong. Selain itu, penemuan genetika turut disusul oleh penemuan struktur spiral ganda DNA oleh James Watson dan Francis Crick setelah Perang Dunia ke-2.

Ted Peters menunjukkan hasil penelitian genetika tersebut telah menggoyangkan pemahaman teologi (agama) dengan dipetakan dalam reduksionisme, determinisme genetika, dan evolusi Neo-Darwin. ${ }^{28}$ Reduksionisme genetika telah menyajikan masalah kepercayaan

\footnotetext{
${ }^{27}$ Franz Magnis-Suseno. Iman dan Hati Nurani: Gereja Berhadapan dengan Tantangan-tantangan Zaman. (Jakarta: Obor, 2014), 186.

${ }^{28}$ Ted Peters, "Genetika, Teologi, dan Etika" dalam Ted Peters dan Gaymon Bennett (peny.). Menjembatani Sains dan Agama (Jakarta: BPK Gunung Mulia, 2006), 115.
} 
kultural yang tidak jelas bahwa semua tergantung pada penemuan gen. Menurut Peters, reduksionisme demikian tampaknya tidak memberi ruang bagi pengaruh independen dari pihak roh atau budaya, sekaligus dua dimensi yang di dalamnya sebagian besar tradisi keagamaan bekerja. Sedangkan, determinisme genetika menyajikan pemahaman apabila "semua tergantung pada gen" dan DNA merupakan cetak biru siapa manusia itu, maka gen telah menduduki posisi sebagai penentu sifat dan nilai manusia. Namun para teolog (agamawan) menegaskan determinisme tersebut sebenarnya tidak hanya berkenaan dengan gen saja, melainkan harus menyentuh unsur lingkungan dan diri manusia atau pribadi.

Lalu, evolusi Neo-Darwin perlu dilihat dalam dua konteks pada abad ke-19 dan 20. Determinisme abad ke-19 menggunakan seleksi alam sebagai mekanisme untuk menjelaskan perubahan evolusioner dari waktu ke waktu. Sedangkan, determinisme abad ke-20 menambahkan mutasi genetika pada teori tersebut dengan memberikan penjelasan terperinci tentang bagaimana seleksi alam berlangsung. Dengan kata lain, Peters menunjukkan sosiobiolog menyimpulkan dari Neo-Darwinisme dengan berupaya menjelaskan semua kebudayaan manusia, termasuk kepercayaan religius, dari sudut determinisme biologis. Melihat situasi demikian, para teolog (agamawan/ wati) berpendapat bahwa Yesus menandai kemajuan yang berarti dalam sejarah evolusi, karena dengan orang Nazareth itu, sebuah kehidupan teladan telah dimulai, yang mendahului agenda agen yang mementingkan diri sendiri dan terbuka pula kesempatan bagi kasih yang bersedia mengorbankan diri sendiri. ${ }^{29}$

\section{The Da Vinci Code Dan Brown: Konspirasi Tentang Konspirasi?}

Pada tahun 2003, Kardinal Tarcisio Bertone memrotes novel “The Da Vinci Code Dan Brown". Novel ini membidik cawan suci misterius (the holy grail) di mana Yesus sedang mengkonsekrasikan anggur menjadi darah-Nya pada perjamuan terakhir, dan di dalamnya Maria Magdalena, di bawah salib, menampung darah yang keluar dari lambung Yesus sesudah ditusuk tombak. ${ }^{30}$ Cawan itu dikisahkan dijaga oleh the priory of Sion (sebuah organisasi amat rahasia). Apa maksudnya? Cawan suci tersebut dipahami sebagai gambaran rahim Maria Magdalena sendiri, dan yang ditampung bukan darah Yesus, melainkan janin hasil perkawinannya dengan Yesus. Novel The Da Vinci Code disinyalir menunjukkan gereja telah terlibat dalam konspirasi raksasa yaitu menutup-nutupi kenyataan bahwa Yesus sebenarnya hendak menyerahkan pimpinan umat-Nya kepada Maria Magdalena.

\footnotetext{
${ }^{29}$ Peters, "Genetika, Teologi, dan Etika", 116.

${ }^{30}$ Magnis-Suseno. Iman dan Hati Nurani, 197.
} 
Lantas, benarkah semua paparan novel tersebut? Meringkas paparan Dan Burstein, Franz Magnis-Suseno memetakannya dalam tujuh butir berikut ${ }^{31}$ :

1. Benarkah ada the priory of Sion sebagaimana serikat rahasia yang didirikan tahun 1099? Tidak ada bukti sejarah apapun bahwa priority itu ada sebelum 1956. Fakta bahwa yang ditemukan di Perpustakaan Nasional Paris 1975 bukan naskah-naskah kuno, melainkan ketikan mesin tik yang oleh para ahli diperkirakan ditulis pada tahun 1956. Kiranya oleh Pierre Plantard yang mengangkat diri menjadi grand masternya dan yang tidak pernah mengklaim bahwa priority itu ada kaitan apapun dengan the holy grail.

2. Benarkah tarekat Templar, di abad ke-12, menemukan dokumen-dokumen tentang the holy grail di Yerusalem? Ternyata taka da dokumen sejarah satu pun mengenai hal itu. Dan tentu, jika dokumen-dokumen itu ada akan dibawa oleh Maria Magdalena waktu itu, menurut Dan Brown, melarikan diri ke Perancis, daripada dibiarkan di tempat musuh-musuhnya. Tambahan lagi, penumpasan tarekat Templar 1314 tidak didalangi Paus, melainkan oleh Raja Perancis yang ingin merampas kekayaan mereka.

3. Benarkah Maria Magdalena, dalam keadaan hamil dari Yesus lari ke Perancis, hidup dengan bermatiraga? Benarkah bahwa raja-raja Perancis pertama, kaum Merowing merupakan keturunan Yesus? Yang benar ialah bahwa legenda tentang pendaratan Maria Magdalena di Perancis untuk pertama kalinya muncul di abad ke-11 di Perancis Selatan, sekitar seribu tahun sesudah wafat Maria Magdalena. Raja-raja Merowing memang menyatakan diri keturunan dari berbagai nenek moyang mitis, tetapi tidak pernah dari Yesus. Secara literatur, Dan Brown rupanya telah mengambil alih perihal keturunan Yesus dari buku Holy Blood, Holy Grail karangan Michael Baigent, Richard Leigh, dan Henry Lincoln tahun 1982 yang hanya hisapan jempol belaka.

4. Benarkah perkawinan Yesus dengan Maria Magdalena merupakan fakta sejarah ( $a$ matter of historical record)? Tidak benar! Tidak ada laporan, data, sindiran, dan dokumen sejarah apapun. Guna mengartikan pesta perkawinan di Kana sebagai pesta perkawinan Yesus dengan Maria Magdalena tidak ada dasar serius apapun.

5. Benarkah bahwa Yesus sudah pasti kawin karena ia orang Yahudi, tetapi hal itu kemudian ditutup-tutupi oleh gereja purba? Dua-duanya tidak ada hubungannya karena waktu zaman Yesus, ada juga kelompok-kelompok Yahudi yang tidak kawin, khususnya umat di Qumran (dead sea scrolls). Kalaupun Yesus benar berkeluarga,

\footnotetext{
${ }^{31}$ Magnis-Suseno. Iman dan Hati Nurani, 199-202.
} 
gereja purba tidak akan memiliki alasan apapun untuk merahasiakannya justru karena pada umumnya para rabbi Yahudi terhormat dan juga para nabi memang berkeluarga dan pernikahan tidak akan menurunkan gengsi Yesus di mata para pengikutnya.

6. Benarkah ada Injil selain Matius, Markus, Lukas, dan Yohanes yang ditolak oleh gereja? Benar. Di luar keempat Injil resmi tersebut ada beberapa Injil lain yang oleh gereja sejak abad ke-2 ditolak sebagai beraliran sesat. Namun, Injil-injil tersebut disebut apokrif dengan perkecualian Injil Thomas, bukan Injil dalam arti kisah hidup Yesus melainkan kumpulan ajaran. 56 naskah kuno semacam itu kebetulan ditemukan tahun 1945 di Nag Hammani di Mesir. Berbagai teks yang beraneka ragam itu berasal dari aliran gnosis. Kaum gnosis sendiri mengajarkan bahwa penebusan tidak terjadi melalui pertobatan dan pengampunan dosa, melainkan melalui pencapaian suatu pengetahuan lebih luhur yang tidak terbuka bagi orang banyak.

7. Benarkah di antara tulisan-tulisan Nag Hammadi terdapat Injil Maria Madgalena dan Injil Philipus yang memuat kebenaran tentang Yesus dan the holy grail? Benar. Namun, Injil Maria tidak menceritakan hidup Yesus, melainkan bagaimana Maria Magdalena memberi ajaran kebijaksanaan kepada para rasul. Injil Philipus menulis Yesus mencintai Maria Magdalena lebih daripada semua murid lain dan suka mencium mulutnya. Menurut para ahli, ciuman tersebut tidak dimaksudkan dalam arti seksual, melainkan Maria Magdalena dipercayai sebagai tokoh gnosis yang memiliki pengetahuan istimewa. Injil-injil tersebut tidak berbicara mengenai kepemimpinan gereja, melainkan menolak gereja dalam arti umat luas yang tersusun hierarkis.

Uraian di atas merupakan tanggapan atas novel The Da Vinci Code. Masih banyak lagi fakta lain dalam novel yang tidak benar, di antaranya sebelum Konsili Nicea pada $325 \mathrm{M}$, Yesus tidak dipercayai berkodrat Ilahi bahwa kaisar Konstantin menyuruh membuat Kitab Suci baru demi tujuan politiknya bahwa dalam Injil-Injil resmi, semua segi kemanusiaan Yesus telah dihilangkan dan tulisan Qumran merupakan dokumen Kristiani pertama di mana tida ada apapun mengenai Yesus maupun Kristianitas dalam tulisan tersebut sehingga mereka murni Yahudi. ${ }^{32}$ Lantas, apakah Brown bersama dengan Baigent, Leigh, dan Lincoln terlibat dalam sebuah konspirasi melawan gereja? Tentu tidak. Masalah novel itu ialah Brown menyatakannya sebagai fiksi, tetapi pada waktu yang sama memakai cukup banyak fakta, nama-nama, dan benda-benda yang dikenal baik sehingga semua menimbulkan kesan fakta.

\footnotetext{
${ }^{32}$ Franz Magnis-Suseno. Iman dan Hati Nurani, 203.
} 


\section{Ketegangan Terbuka dan Kreatif}

Pertanyaan mendasarnya: "Apakah sains dan agama masing-masing menawarkan sesuatu yang bernilai intelektual?" Hal ini tentu tidak mudah. Setidaknya, Robert Russell memetakannya berikut dengan menggunakan ilmu Fisika sebagai obyeknya. ${ }^{33}$ [1] Teori-teori Fisika dapat bertindak sebagai data yang membatasi teologi (agama), contohnya teologi (agama) tentang tindakan Ilahi yang seharusnya tidak melanggar relativitas khusus. [2] Teoriteori Fisika dapat bertindak sebagai data untuk dimasukkan ke teologi (agama), contohnya awal waktu atau $\mathrm{t}=0$ dalam kosmologi Big Bang dapat dijelaskan melalui penciptaan ex nihilo yang terintegrasi dengan penjelasan teologi (agama). [3] Teori-teori dalam Fisika dapat bertindak secara tidak langsung sebagai data dalam teologi, contohnya $\mathrm{t}=0$ dapat ditafsirkan secara filosofis sebagai bukti ketergantungan dalam alam semesta Big Bang dan dimungkinkan menyiratkan keberadaan Allah. [4] Teori-teori dalam Fisika dapat bertindak secara tidak langsung sebagai data teologi (agama) apabila mereka digabungkan dengan filsafat alam. Kemudian, [5] Teori-teori dalam Fisika dapat berfungsi secara heuristik dalam konteks penemuan teologis dengan memberikan inspirasi konseptual, eksperensial, moral, atau estetis.

Di samping berangkat dari Fisika, Russel turut mengembangkannya melalui teologi (agama) sebagai pijakannya. Pemikiran tersebut tertuang sebagai berikut ${ }^{34}$; [1] Teologi telah memberikan asumsi-asumsi historis utama yang mendasari perkembangan sains, misalnya kemungkinan dan rasionalisme alam. [2] Teori-teori teologi dapat bertindak sebagai sumbersumber inspirasi dalam proses penemuan ilmiah, contohnya pengaruh gagasan religius pada perintis teori kuantum. [3] Teori-teori teologi (agama) dapat memberikan kriteria berupa empiris, koherensi, jangkauan, dan fertilitas bagi pemilihan teori dalam Fisika.

\section{Kesimpulan}

Berpijak pada jenis tantangan ke depan, kita harus mulai menyadari bahwa sains dan agama (teologi) harus diupayakan masuk dalam kondisi yang sama-sama terbaik. Hal tersebut dikarenakan keduanya telah mencari kebenaran dengan berbagai jalan. Jalan itu bisa dimungkinkan membangun hubungan antara satu dengan lainnya. Bila perlu, upaya menghubungkan itu diupayakan masuk pada integrasi. Model integrasi menunjukkan adanya pertemuan antara sains dan agama secara sintesis sehingga menghasilkan kajian baru. Tujuan sintesis di sini berupaya menggabungkan keduanya dalam suatu kerangka tunggal. Melalui

\footnotetext{
${ }^{33}$ Russell dan Monelly, "Sains dan Teologi: Interaksi Timbal-Balik”, 41-42.

${ }^{34}$ Ibid.
} 
cara demikian, konsep ruang, waktu, materi, kausalitas, pikiran, roh, dan Allah telah digunakan secara sintesis dalam teori dan penelitian teologis maupun ilmiah. Dengan adanya menghubungkan antara sains dan agama, kita bisa mencoba melihat, memahami alam semesta besar di luar, memahami mengapa kita ada di sini. Maka, upaya menghubungkan tersebut dimungkinkan bisa diberikan pandangan yang berbeda.

\section{Referensi}

D. Breck, Allen dan Wolfgang Yourgrau (eds.) Biology, History, and Natural Philosophy. New York: Plenum Publishing Corporation, 1974.

Delio OSF, Ilia. Is Natural Law “Unnatural?” Exploring God and Nature Through Teilhard's Organic Theology. Theology and Science Journal, Volume 15, 2017, Issue 3, 276288. https://doi.org/10.1080/14746700.2017.1335063

Dodds OP, Michael J. Thomas Aquinas vis-à-vis Natural Theology, Theology of Nature, and Religious Naturalism. Theology and Science Journal, Volume 15, 2017, Issue 3, 266275. https://doi.org/10.1080/14746700.2017.1335062

Dua, Mikhael. Filsafat Ilmu Pengetahuan. Maumere: Ledalero, 2009.

Early. Christian. Theology After the Scientific Revolution: The Significance of Nancey Murphy's Contribution to Philosophy of Religion. Theology and Science Journal, Volume 15, 2017, Issue 4, 440. https://doi.org/10.1080/14746700.2017.1369756

J. Ayala, Francisco. Darwins's Gift to Science and Religion. Washington DC: Joseph Henry Press, 2007.

Leahy, Louis. Manusia di Hadapan Allah 1: Masalah Ketuhanan Dewasa Ini. Yogyakarta/ Jakarta: Kanisius/ BPK Gunung Mulia, 1982.

. Sains dan Agama dalam Konteks Zaman Ini. Yogyakarta: Kanisius, 1997.

Magnis-Suseno, Franz. Allah dan Alam: Darwinisme, Creationism, dan Intelligent Design. Jurnal Diskursus Vol. 8, No. 1, April 2009. Iman dan Hati Nurani: Gereja Berhadapan dengan Tantangantantangan Zaman. Jakarta: Obor, 2014.

Peters, Ted. dan Gaymon Bennet (Peny.). Menjembatani Sains dan Agama terj. Jessica Christiana Pattinasarany. Jakarta: BPK Gunung Mulia/ CTNS, 2006.

Peters, Ted. Naturalisms: Scientific? Religious? Theological? Theology and Science Journal, Volume 15, 2017, Issue 3, 302-320. https://doi.org/10.1080/14746700.2017.1335059

Peters, Ted. Science and Religion: Ten Models of War, Truce, and Partnership. Theology and Science Journal, Volume 16, 2018, Issue 1, 11-53. https://doi.org/10.1080/14746700.2017.1402163

Russell, Robert John. Theological Influences in Scientific Research Programs: Natural Theology “in Reverse”. Theology and Science Journal, Volume 15, 2017, Issue 4, 378-394. https://doi.org/10.1080/14746700.2017.1369751

Rey, Kevin Tonny. "Konstruksi Teologi Dalam Konteks Reposisi Pemikiran Warga Gereja." EPIGRAPHE: Jurnal Teologi dan Pelayanan Kristiani 2, no. 1 (2018): 1-13. www.stttorsina.ac.id/jurnal/index.php/epigraphe.

Saragi, Marojahan. "Ancaman Evolusionisme Terhadap Pendidikan Kristen.” KURIOS (Jurnal Teologi dan Pendidikan Agama Kristen) 3, no. 1 (2015): 40-47. www.sttpb.ac.id/e-journal/index.php/kurios.

Sihombing, Bernike. "Studi Penciptaan Menurut Kitab Kejadian 1 : 1-31.” KURIOS (Jurnal Teologi dan Pendidikan Agama Kristen) 1, no. 1 (2013): 1-31. 